
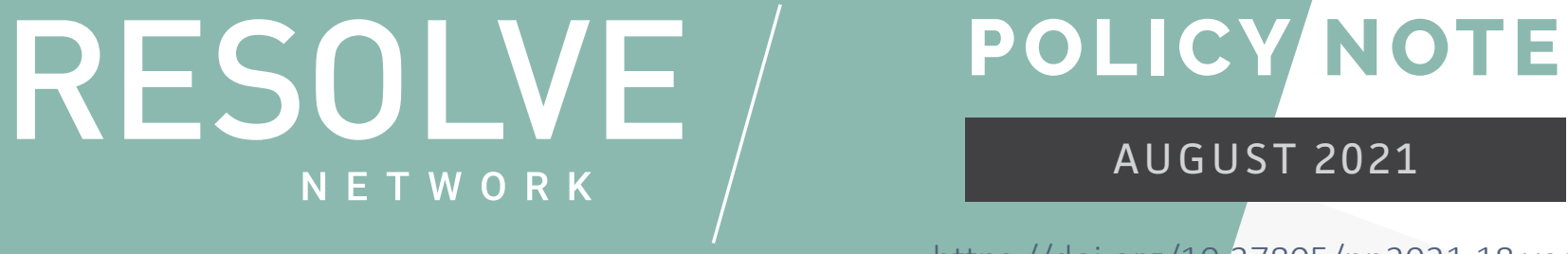

https://doi.org/10,37805/pn2021.18.vedr

\title{
DERADICALIZATION PROGRAMS: RECOMMENDATIONS FOR POLICY AND PRACTICE
}

\author{
JOHN HORGAN
}

VIOLENT EXTREMIST

DISENGAGEMENT AND RECONCILIATION

\section{${ }^{6}$ Deradicalization programs represent a creative approach}

\section{to addressing violent extremism. Their existence signals a commitment to rehabilitation and reintegration."}

\section{FAST FACTS Context}

$\rightarrow$ Deradicalization programs, if effectively developed, can reduce the risk of re-engagement in vio-

lent extremism.

$\rightarrow$ For deradicalization initiatives to be effective, they must be aware of and have access to research.

$\rightarrow$ Monitoring, measurement, and evaluation ought to be built into future programming to ensure rigorous and transparent analysis of

effectiveness.

$\rightarrow$ Thinking more creatively about what constitutes success is essential, as well as how deradicalization programs contribute to the broader objective of building peace in communities affected by conflict.
Involvement in violent extremism is not a one-way street. People can, and do, leave violent extremist movements. Understanding how and why they leave (or want to leave) constitutes actionable knowledge that brings immense practical benefits. Such knowledge may help in designing initiatives aimed at persuading people to leave violent extremist groups as well as reducing the risk of re-engagement in violent extremism in the future.

The processes involved are disengagement and deradicalization. They are both related and distinct.

- Disengaging means stopping one's involvement in violent extremist behavior. A decade of empirical research shows that this can happen for many reasons, with several factors affecting this. Disillusionment is a common theme across groups and ideologies.

- Deradicalizing means changing one's views about involvement in violent extremism. That can also 
happen for many reasons. ${ }^{1}$

Someone can be both disengaged and deradicalized-that is, they have ceased to be involved in violent extremism and no longer support the ideas, or ideology, behind the group or its actions. Alternatively, someone might be disengaged yet not deradicalized. That is, they have ceased to be involved without necessarily refuting their ideological or emotional commitment to a movement or cause.

Understanding whether or not someone is deradicalized is an important element in assessing the risk of them re-engaging in violent extremism. Reducing ideological commitment seems like a critical factor in reducing the risk of recidivism, but ideology is often only one of several issues that need to be addressed. Understanding the specific context in which violent extremism exists is essential for assessing the people who engage in it, as is understanding the multiplicity of factors that drive and sustain their involvement.

To that end, dozens of initiatives worldwide-collectively and informally known as deradicalization programs-were established with the overarching goal of reducing the risk of re-engagement in violent extremism. How these programs aspire to this goal varies from country to country and program to program. One program may place more emphasis on addressing ideology than another, but the task of assessing risk of re-engagement in terrorism is largely about understanding individual-level risk factors present (or absent) in the person being assessed-in other words, figuring out why a particular person may be at risk of re-engagement and what can be done to help mitigate that risk for them. Whether such programs work is a deeply contentious issue. They are rarely subject to evaluation. A failure to embrace measurement and evaluation as standard components of deradicalization programming now threatens their long-term future and viability.

Deradicalization programs have much to offer but they are not a magic solution to a highly complex, fluid problem. Not everyone who engages in violent extremism is necessarily going to benefit from such interventions, and no program can ever expect to produce complete success. Yet, they continue to show promise. Deradicalization programs can be effective for some and, if subjected to greater evaluation efforts, may prove far more beneficial than is currently believed. Despite an abundance (and apparent increase) in programming, a continued lack of evaluation work both fuels skepticism and hinders our ability to believe that there is a strong future for these programs.

\section{Relevance to Policy and Practice}

Deradicalization programs, if effectively developed, can reduce the risk of re-engagement in violent extremism. The existence of such programs may also attract those who wish to disengage from violent extremism but do not see a viable exit. Credible former members of extremist groups can act as powerful voices to encourage disengagement in others in their networks and dissuade potential future generations of militants by deglamorizing and delegitimizing involvement. ${ }^{2}$

1 Chris Bosley, Violent Extremist Disengagement and Reconciliation: A Peacebuilding Approach, United States Institute of Peace, July 29, 2020, https://www.usip.org/publications/2020/07/violent-extremist-disengagement-and-reconciliation-peacebuilding-approach.

2 Ryan Scrivens et al., "Combating Violent Extremism: Voices of Former Right-Wing Extremists," Studies in Conflict \& Terrorism (2019), https://doi.org/10.1080/1057610X.2019.1686856. 
Deradicalization programs are not just about thinning the ranks of violent extremist groups but equally about promoting reintegration and reconciliation in communities affected by conflict. ${ }^{3}$ These programs can foster legitimacy and inclusion in such communities. It signals to those communities that states need not exclusively rely on repressive means in countering or preventing future violent extremism and that communities have a voice in efforts to resolve conflict by addressing longer-term issues. ${ }^{4}$

The earliest deradicalization programs emerged in detention settings in Saudi Arabia, Yemen and elsewhere to manage and rehabilitate violent extremist prisoners that might one day be released. ${ }^{5}$ The government agencies behind such programs recognized multiple potential benefits to their existence, ranging from learning more about the movement itself, fostering voices that might be critical of the movement and its propaganda, and increasing the perceived legitimacy of the government at home and abroad. Rehabilitation and reintegration can also reduce the financial burden of keeping incarcerated large numbers of former militants.

In 2021, there are dozens of deradicalization programs worldwide. The total number is difficult to estimate. Several fledgling efforts exist in the shadows until they either expand in size or feel sufficiently confident to advertise their existence. Others are widely known: Saudi Arabia's program is well-resourced and in existence for well over a decade, for instance. As with all these programs, context is everything - low recidivism in Saudi Arabia may owe more to stringent security conditions and the ability to threaten and impose severe penalties for those who even appear in breach of agreements. ${ }^{6}$ France's program, launched in 2016, was shut down after only five months because it was deemed to be poorly designed and placed too much emphasis on ideology without ascertaining whether it mattered for individual participants in the program. ${ }^{7}$ Other programs are small, existing thanks to the efforts of a few dedicated people with few resources. ${ }^{8}$

All deradicalization programs share the same primary objective: to reduce the risk of reengagement in terrorism. How they strive to achieve this varies considerably. Almost all programs employ multiple intervention types including psychological counseling and therapies (of various kinds), ideological debates, family support, restorative justice (e.g., meeting with victims) and vocational trainings. ${ }^{9} \mathrm{~A}$ common thread in the interventions is providing the participant with the building blocks to shape and nurture a new identity.

3 Bosley, Violent Extremist Disengagement.

4 Tore Bjørgo and John Horgan, eds., Leaving Terrorism Behind: Individual and Collective Disengagement (London: Routledge, 2009).

5 John Horgan and Mary Beth Altier, "The future of de-radicalization programs," Georgetown Journal of International Affairs 13, no. 2 (Summer/Fall 2012): 83-90, https://www.jstor.org/stable/43134238.

6 Christopher Boucek, "Extremist re-education and rehabilitation in Saudi Arabia," in Leaving Terrorism Behind: Individual and Collective Disengagement, eds. Tore Bjørgo and John Horgan (London: Routledge, 2009), 212-223.

7 Elena Souris and Spandana Singh, "Want to deradicalize terrorists? Treat them like everybody else," Foreign Policy, November 23, 2018, https://foreignpolicy.com/2018/11/23/want-to-deradicalize-terrorists-treat-them-like-everyone-else-counterterrorism-deradicalization-france-sri-lanka-pontourny-cve/.

8 Jeremy Moore, How Pakistan Deradicalizes Taliban Fighters, United States Institute of Peace, October 11, 2018, https://www. usip.org/publications/2017/10/how-pakistan-deradicalizes-taliban-fighters.

9 For example, see: Bjørgo and Horgan, Leaving Terrorism behind; Bosley, Violent Extremist Disengagement; Mary Beth Altier, Violent Extremist Disengagement and Reintegration: Lessons from Over 30 Years of DDR (Washington, D.C.: RESOLVE Network, 2021), https://doi.org/10.37805/vedr2021.1. 
Early criticisms of deradicalization programs were vocal, ${ }^{10}$ many surrounding allegations of lack of transparency. Several programs continue to be accused of representing 'soft' approaches to undeserving recipients when punishment seems more appropriate. ${ }^{11}$ Programs were also faced with the social and political risk associated with even one case of recidivism. Though violent extremism is a rare activity, even one successful attack by a person deemed to have been 'rehabilitated' could bring substantial political repercussions. ${ }^{12}$

Yet, the main criticism leveled at deradicalization programs is about their effectiveness. Whether they actually achieve what we think (or what they say) they achieve, is questionable. Results are, at best, mixed. ${ }^{13}$ Many programs claim tremendous success while offering little to no transparency on how they achieved their objectives, how they measure success, and who are the participants. Some programs are criticized because participants are sometimes people who exist only on the fringes of movements, with no involvement in violence. ${ }^{14}$ The majority of these programs have not been evaluated. Those that have continue to rely on "expert impressions and potentially flawed recidivism rates." 15

Effective programs must have valid and reliable screening processes to assess whether a participant's intentions are genuine. Once a participant graduated from a program and has been released from prison, post-release monitoring must begin. Albeit a highly resource-intensive process, it is critical for monitoring progress and managing risk-not only risk of recidivism but of reprisals from former comrades and/or security forces.

\section{Recommendations}

\section{Transform and translate research into practice}

We know far more about disengagement than ever before, both within and across groups and ideologies. A decade of high-quality research on disengagement offers actionable knowledge and solutions informed by evidence. ${ }^{16}$ However, this research has emerged in parallel with the rise of deradicalization programs, not in tandem with it. For deradicalization initiatives to be effective,

10 Bjørgo and Horgan, Leaving terrorism behind.

11 Helen Lewis, "Why Extremists Need Therapy," The Atlantic, February 11, 2020, https://www.theatlantic.com/international/ archive/2020/02/britain-london-terrorism-deradicalization/606376/.

12 Douglas Weeks, "Lessons learned from U.K. efforts to deradicalize terror offenders," CTC Sentinel 14, no. 3 (March 2021), https://www.ctc.usma.edu/lessons-learned-from-u-k-efforts-to-deradicalize-terror-offenders/.

13 Bart Schuurman and Edwin Bakker, "Reintegrating jihadist extremists: Evaluating a Dutch initiative, 2013-2014," Behavioral Sciences of Terrorism and Political Aggression 8, no. 1 (2016): 66-85, https://doi.org/10.1080/19434472.2015.1100648.

14 For example, see: Zubair Azam and Syeda Bareeha Fatima, "Mishal: A case study of a Deradicalization and Emancipation Program in SWAT Valley, Pakistan," Journal for Deradicalization 11 (Summer 2017), https://journals.sfu.ca/jd/index.php/ jd/article/view/97; for subsequent discussion of this and related studies, see John Horgan, Katharina Meredith, and Katerina Papatheodorou, "Does deradicalization work?," Sociology of Crime, Law and Deviance 25, (2020): 9-20, https://doi. org/10.1108/s1521-613620200000025001.

15 David Webber et al., “Deradicalizing detained terrorists," Political Psychology 39, no. 3 (2018): 539-556, https://doi. org/10.1111/pops.12428.

16 For example, see: Altier, Violent Extremist Disengagement and Reintegration; Sarah Marsden, Reintegrating Extremists: Deradicalisation and desistance (London: Palgrave Macmillan, 2017); Bosley, Violent Extremist Disengagement and Reconciliation. 
they must be aware of and have access to this research. Policymakers can facilitate interactions between the research and practitioner communities, ensuring mutual benefits. Researchers can learn about the real-world challenges faced by practitioners, while practitioners can be better informed about the emerging science on these issues. Such interaction will facilitate translation of research into practice, where applicable and appropriate, thus contributing to longer-term sustainability of programmatic efforts.

\section{Fund and promote evaluation}

Many deradicalization programs do not do evaluation-yet. A common excuse is that it is too difficult and time-consuming or that the program first needs to develop fully before it can be evaluated. These are false propositions, often reflecting genuine anxieties about what evaluation involves and implies. The idea of evaluation can seem threatening to a fledgling program, yet evaluation efforts are imperative not only to see if programs achieve their objectives but to ensure transparency and accountability and enhance public trust in such initiatives.

Monitoring, measurement, and evaluation ought to be built into future programming to ensure rigorous and transparent analysis of effectiveness. Program evaluation is not easy, as anyone who has worked on the ground in such environments would attest, and all evaluations must reflect the respective time and place of implementation. These challenges, however daunting, must not prevent meaningful implementation of evaluation efforts.

\section{Understand what success (and failure) means}

Many programs fail to evaluate because they fail to specify their objectives. Programs are often reluctant to outline timely objectives because they are not sure if they can meet them in the set timeframe. But success cannot be measured by looking at recidivism rates alone. Recidivism to violent extremism appears to be low irrespective of participation in deradicalization programs. Therefore, a challenge for deradicalization programs is to demonstrate their added value beyond reducing recidivism - encouraging programs to no longer be guided by pursing a zero-percent recidivism rate is necessary. Thinking more deeply and creatively about what constitutes success is essential, as well as how deradicalization programs contribute to the broader objective of building peace in and between communities affected by conflict.

Furthermore, success is both incremental and changeable. Progress by a program that has been running for only twelve months might be very different compared to a program running for over a decade. In the case of the former, more immediate and short-term objectives (e.g., simply operating for twelve months or generating initial funding or resources) matter far more than attempting to ensure reduced recidivism for participants, the bulk of whom have not yet had an opportunity to participate in the actual program. As programs develop, so too will expectations. Meaningful evaluation will reflect this.

What may be relevant in the first year of a program (e.g., earning the trust of local stakeholders, generating initial resources etc.) will likely change in year two (e.g., increasing buy-in from stakeholders etc.), year three (e.g., increasing voluntary participation from former militants) or year four (e.g. engaging with scientists and practitioners to incorporate theories of change into programmatic efforts) and so on. 


\section{Temper expectations and study failures}

Deradicalization programs face too much criticism in part because people expect too much of them. Deradicalization is neither a deliverable nor an outcome-it is a process. Deradicalization programs can facilitate that process. As programs develop, so too will their own sense of realistic progress from year to year. Meaningful evaluation efforts not only help identify successively ambitious progress markers but can course-correct if prevailing conditions change. They can neither solve the problem of violent extremism, nor guarantee success. They are not for everyone, and they will not be effective for all who even willingly participate in them. No deradicalization program can be expected to be one hundred percent successful. Programs must be encouraged to showcase failures as well as successes. This is a critical element for learning what works and why and in ensuring the continued transparency, credibility, and success of programs.

\section{Conclusions}

Deradicalization programs represent a creative approach to addressing violent extremism. Their existence signals a commitment to rehabilitation and reintegration. They are one element of not just counterterrorism but rebuilding communities often torn apart by violent extremism. But they can only be effective if properly resourced, informed by evidence, rigorously evaluated, and rooted in the affected communities. Research from the scientific community can greatly contribute to the long-term sustainability of deradicalization programs. Evaluation of these programs and their progress is equally critical to ensure their continued future. Policymakers can help build bridges, promoting greater cooperation between otherwise diverse communities of scientists and practitioners. Furthermore, programs must be encouraged to not just build evaluation into their efforts from the outset but understand the value of what evaluation brings. Rather than seeing it as a potential threat to its future, programs must understand that evaluation helps ensure a future for such programs.

\section{Suggested Further Reading}

\section{On Deradicalization Theory and Process}

Altier, Mary Beth, Emma Leonard Boyle, Neil D. Shortland, and John G. Horgan. "Why they leave: An analysis of terrorist disengagement events from eighty-seven autobiographical accounts." Security Studies 26, no. 2 (April 3, 2017): 305-332. https://doi. org/10.1080/09636412.2017.1280307.

Altier, Mary Beth, Christian Thoroughgood, and John Horgan. "Turning Away from Terrorism: Lessons from Psychology, Sociology, and Criminology." Journal of Peace Research 51, no. 5 (2014): 647- 661. https://doi.org/10.1177\%2F0022343314535946.

Bjorgo, Toro, and John Horgan. Leaving terrorism behind: Individual and collective disengagement. London: Routledge, 2009.

da Silva, Raquel, Pablo Fernández-Navarro, Miguel M. Gonçalves, Catarina Rosa, and Joana Silva. "Disengagement from political violence and deradicalization: A narrative-dialogical perspective." Studies in Conflict \& Terrorism 43, no. 6 (June 2, 2020): 444-467. https://doi.org/10.1080/1057610x.2018.1452709.

Ebaugh, Helen Rose Fuchs. Becoming an Ex: The process of role exit. Chicago, IL: University of Chicago Press, 1988. https://doi. org/10.7208/chicago/9780226160535.001.0001. 
Grip, Lina, and Jenniina Kotajoki. "Deradicalisation, disengagement, rehabilitation and reintegration of violent extremists in conflict-affected contexts: A systematic literature review." Conflict, Security and Development 19, no. 4 (July 4, 2019): 371402. https://doi.org/10.1080/14678802.2019.1626577.

Harris, K. J., E. Gringart, and D. Drake. "Leaving ideological groups behind: A model of disengagement." Behavioral Sciences of Terrorism and Political Aggression 10, no. 2 (2018): 91-109. https://doi.org/10.1080/19434472.2017.1299782.

Horgan, John, Katharina Meredith, Katerina Papatheodorou. "Does deradicalization work?." In Radicalization and Counter-Radicalization (Sociology of Crime, Law and Deviance, Vol. 25) edited by Derek M. D. Silva and Mathieu Deflem, 9-20. Bingley: Emerald Publishing Limited, 2020. https://doi.org/10.1108/s1521-613620200000025001.

Koehler, Daniel. Understanding deradicalization: Methods, tools and programs for countering violent extremism. New York, NY: Routledge, 2017.

La Palm, Marita. "Re-purposing the push-pull model to describe signature patterns of terrorist dis- engagement by group: A validation study." Journal for Deradicalization 12 (Fall 2017): 85-118. https://journals.sfu.ca/jd/index.php/jd/article/view/112.

Marsden, Sarah V. Reintegrating extremists: Deradicalisation and desistance. London: Palgrave Macmillan, 2017.

Raets, Sigrid. "The we in me. Considering terrorist desistance from a social identity perspective." Journal for Deradicalization 13 (Winter 2017): 1-28. https://journals.sfu.ca/jd/index.php/jd/article/view/122.

Sieckelinck, Stijn, Elga Sikkens, Marion van San, Sita Kotnis, and Micha De Winter. "Transitional journeys into and out of extremism. A biographical approach." Studies in Conflict \& Terrorism 42, no. 7 (2019): 662-682. https://doi.org/10.1080/10576 10x.2017.1407075.

Simi, Peter, Steven Windisch, Daniel Harris, and Gina Ligon. "Anger from within: The role of emotions in disengagement from violent extremism." Journal of Qualitative Criminal Justice \& Criminology 7, no. 2 (2019): 3-28. https://digitalcommons.chapman.edu/sociology articles/53/.

Windisch, Steven, Gina Scott Ligon, and Pete Simi. "Organizational [dis]trust: Comparing disengagement among former left-wing and right-wing violent extremists." Studies in Conflict \& Terrorism 42, no. 6 (2019): 559-580. https://doi.org/10.1080/10576 10x.2017.1404000.

Windisch, Steven, Pete Simi, Gina Sott Ligon, and Hillary McNeel. "Disengagement from ideologically-based and violent organizations: A systematic review of the literature." Journal for Deradicalization 9 (Winter 2016/2017): 1-38. https://journals.sfu.ca/ jd/index.php/id/article/view/72/65.

\section{On Recidivism}

Altier, Mary Beth, Emma Leonard Boyle, and John G. Horgan. (2019). "Returning to the fight: An empirical analysis of terrorist reengagement and recidivism." Terrorism and Political Violence 33, no. 4 (2021): 836-860. https://doi.org/10.1080/0954655 3.2019.1679781.

Hodwitz, Omi. "The terrorism recidivism study (TRS) examining recidivism rates for post-9/11 offenders." Perspectives on Terrorism 13, no. 2 (2019): 54-64. https://www.jstor.org/stable/26626865? seq=1\#metadata info tab contents.

Wright, Christopher. "An examination of Jihadi Recidivism Rates in the United States." CTC Sentinel 12, no. 10 (November 2019). https://ctc.usma.edu/examination-jihadi-recidivism-rates-united-states/.

\section{On Country-Specific Experiences of Disengagement and Deradicalization}

Ahmad, Hafal. "Youth de-radicalization: A Canadian framework." Journal for Deradicalization 12 (Fall 2017): 119-168. https:// journals.sfu.ca/jd/index.php/jd/article/view/113/94. 
Alonso, Rogelio, and Javier Díaz Bada. "What role have former ETA terrorists played in counterterrorism and counterradicalization initiatives in Spain?." Studies in Conflict and Terrorism 39, no. 11 (November 2016): 982-1006. https://doi.org/10.1080 L1057610x.2016.1154365.

Azam, Zubair, and Syeda Bareeha Fatima. "Mishal: A case study of a Deradicalization and Emancipation Program in SWAT Valley, Pakistan." Journal for Deradicalization 11 (Summer 2017), https://journals.sfu.ca/jd/index.php/jd/article/view/97.

Chernov-Hwang, Julie. Why terrorists quit: The disengagement of Indonesian Jihadists. Ithaca, NY: Cornell University Press, 2018.

Clubb, Gordon. Social movement de-radicalisation and the decline of terrorism: The morphogenesis of the Irish Republican Movement. London: Routledge, 2016. https://www.routledge.com/Social-Movement-De-Radicalisation-and-the-Decline-of-Terrorism-The-Morphogenesis/Clubb/p/book/9780367596033.

Clubb, Gordon. "The role of Former Combatants in preventing youth involvement in terrorism in Northern Ireland: A framework for assessing Former Islamic State Combatants." Studies in Conflict \& Terrorism 39, no. 9 (September 2016): 842-861. https:// doi.org/10.1080/1057610x.2016.1144917.

Clubb, Gordon, and Marina Tapley. "Conceptualising de-radicalisation and former combatant re-integration in Nigeria." Third World Quarterly 39, no. 11 (November 2, 2018): 2053-2068. https://doi.org/10.1080/01436597.2018.1458303.

Khalil, James, Rory Brown, Chris Chant, Peter Olowo, and Nick Wood. Deradicalization and disengagement in Somalia: Evidence from a rehabilitation programme for former members of Al-Shabaab. Royal United Services Institute Whitehall Report 4-18. Whitehall, London: Royal United Services Institute for Defence and Security Studies, 2019. https://rusi.org/explore-ourresearch/publications/whitehall-reports/deradicalisation-and-disengagement-in-somalia-evidence-from-a-rehabilitationprogramme-for-former-members-of-al-shabaab.

Lowry, Kevin D. "Responding to the challenges of violent extremism/terrorism cases for United States Probation and Pretrial Services." Journal for Deradicalization 17 (Winter 2018/2019): 28-88. https://journals.sfu.ca/id/index.php/id/article/ view/175/130.

Mattsson, Christer, and Thomas Johansson. "Becoming, belonging and leaving: Exit processes among young Neo-Nazis in Sweden." Journal for Deradicalization 18 (Fall 2018): 185-216. https://journals.sfu.ca/id/index.php/id/article/view/161/125.

Mitchell, Stefanie. "Deradicalization: Using triggers for the development of a US Program." Journal for Deradicalization 9 (Winter 2016/2017): 101-125. https://journals.sfu.ca/jd/index.php/jd/article/view/74/67.

Schuurman, Bart, and Edwin Bakker. "Reintegrating jihadist extremists: Evaluating a Dutch initiative, 2013-2014." Behavioral Sciences of Terrorism and Political Aggression 8, no. 1 (January 2, 2016): 66-85. https://doi.org/10.1080/19434472.2015.1100 $\underline{648}$.

Weeks, Douglas. "Doing Derad: An analysis of the U.K. system." Studies in Conflict \& Terrorism 41, no. 7 (July 3, 2018): $523-$ 540. https://doi.org/10.1080/1057610x.2017.1311107.

\section{On Previously Implemented Deradicalization and Reintegration Models}

Boucek, Christopher. "Saudi Arabia's 'Soft' Counterterrorism Strategy: Prevention, Rehabilitation, and Aftercare." Carnegie Endowment for International Peace, September 2, 2008. https://carnegieendowment.org/2008/09/22/ saudi-arabia-s-soft-counterterrorism-strategyprevention-rehabilitation-and-aftercare-pub-22155.

Cherney, Adrian. "Supporting disengagement and reintegration: Qualitative outcomes from a custody-based counter-radicalisation intervention." Journal for Deradicalization 17 (Winter 2018/2019): 1-27. https://journals.sfu.ca/jd/index.php/jd/article/ view/174/129. 


\section{Bibliography}

Altier, Mary Beth. Violent Extremist Disengagement and Reintegration: Lessons from Over 30 Years of DDR. Washington, D.C.: RESOLVE Network, 2021. https://doi.org/10.37805/vedr2021.1.

Azam, Zubair, and Syeda Bareeha Fatima. "Mishal: A case study of a Deradicalization and Emancipation Program in SWAT Valley, Pakistan." Journal for Deradicalization 11 (Summer 2017), https://journals.sfu.ca/jd/index.php/jd/article/view/97.

Bjørgo, Tore, and John Horgan, eds. Leaving Terrorism Behind: Individual and Collective Disengagement. London: Routledge, 2009.

Bosley, Chris. Violent Extremist Disengagement and Reconciliation: A Peacebuilding Approach. United States Institute of Peace, July 29, 2020. https://www.usip.org/publications/2020/07/violent-extremist-disengagement-and-reconciliation-peacebuildingapproach.

Boucek, Christopher. "Extremist re-education and rehabilitation in Saudi Arabia." In Leaving Terrorism Behind: Individual and Collective Disengagement, edited by Tore Bjørgo and John Horgan, 212-223. London: Routledge, 2009.

Horgan, John, and Mary Beth Altier. "The future of de-radicalization programs," Georgetown Journal of International Affairs 13, no. 2 (Summer/Fall 2012): 83-90. https://www.jstor.org/stable/43134238.

Horgan, John, Katharina Meredith, Katerina Papatheodorou. "Does deradicalization work?." In Radicalization and Counter-Radicalization (Sociology of Crime, Law and Deviance, Vol. 25) edited by Derek M. D. Silva and Mathieu Deflem, 9-20. Bingley: Emerald Publishing Limited, 2020. https://doi.org/10.1108/s1521-613620200000025001.

Lewis, Helen. "Why Extremists Need Therapy." The Atlantic, February 11, 2020. https://www.theatlantic.com/international/ archive/2020/02/britain-Iondon-terrorism-deradicalization/606376/.

Marsden, Sarah V. Reintegrating extremists: Deradicalisation and desistance. London: Palgrave Macmillan, 2017.

Moore, Jeremy. How Pakistan Deradicalizes Taliban Fighters. United States Institute of Peace, October 11, 2018. https://www.usip. org/publications/2017/10/how-pakistan-deradicalizes-taliban-fighters.

Schuurman, Bart, and Edwin Bakker. "Reintegrating jihadist extremists: Evaluating a Dutch initiative, 2013-2014." Behavioral Sciences of Terrorism and Political Aggression 8, no. 1 (January 2, 2016): 66-85. https://doi.org/10.1080/19434472.2015.1100 $\underline{648}$.

Scrivens, Ryan, Vivek Venkatesh, Maxime Bérubé, and Tiana Gaudette. "Combating Violent Extremism: Voices of Former RightWing Extremists." Studies in Conflict \& Terrorism, (2019). https://doi.org/10.1080/1057610X.2019.1686856.

Souris, Elena, and Spandana Singh. "Want to deradicalize terrorists? Treat them like everybody else." Foreign Policy, November 23, 2018. https://foreignpolicy.com/2018/11/23/want-to-deradicalize-terrorists-treat-them-like-everyone-else-counterterrorism-deradicalization-france-sri-lanka-pontourny-cve/.

Webber, David, Marina Chernikova, Arie W. Kruglanski, Michele J. Gelfand, Malkanthi Hettiarachchi, Rohan Gunaratna, Marc-Andre Lafreniere, and Jocelyn J. Belanger. “Deradicalizing detained terrorists." Political Psychology 39, no. 3 (2018): 539-556. https:// doi.org/10.1111/pops.12428.

Weeks, Douglas. "Lessons learned from U.K. efforts to deradicalize terror offenders." CTC Sentine/ 14, no. 3, March 2021. https:// www.ctc.usma.edu/lessons-learned-from-u-k-efforts-to-deradicalize-terror-offenders/. 


\section{About the Note}

Author: Dr. John Horgan

Dr. John Horgan is Distinguished University Professor at Georgia State University in the Department of Psychology where he also directs the Violent Extremism Research Group (VERG). Professor Horgan is an expert on terrorist psychology and his current research examines psychological constraints on tactical choices made by terrorist recruiters, psychological themes associated with messaging in the online Incel community, and rehabilitation and reintegration of former violent extremists. His work is widely published, with books including The Psychology of Terrorism (now in its second edition and published in over a dozen languages worldwide), Divided We Stand: The Strategy and Psychology of Ireland's Dissident Terrorists; Walking Away from Terrorism, Leaving Terrorism Behind, and Terrorism Studies: A Reader. He is an Editor of the journal Terrorism and Political Violence, Consulting Editor of American Psychologist, and Consulting Editor of Psychology of Violence.

The views expressed in this publication are those of the authors. They do not necessarily reflect the views of the RESOLVE Network, the U.S. Institute of Peace, or any entity of the U.S. government.

RESOLVE NETWORK

better research.informed practice.improved policy on violent extremism.

www.resolvenet.org

$\boldsymbol{Y} \boldsymbol{9}$ in. 